\title{
Alcyonium Octocorals: Potential Source of Diverse Bioactive Terpenoids
}

\author{
Ahmed Abdel-Lateff ${ }^{1,2, *}$, Walied Mohamed Alarif ${ }^{3, *}$, Najla Ali Alburae ${ }^{4,5}$ and \\ Mardi Mohamed Algandaby 4 \\ 1 Department of Natural Products and Alternative Medicine, Faculty of Pharmacy, King Abdulaziz University, \\ P.O. Box 80260, Jeddah 21589, Saudi Arabia \\ 2 Department of Pharmacognosy, Faculty of Pharmacy, Minia University, Minia 61519, Egypt \\ 3 Department of Marine Chemistry, Faculty of Marine Sciences, King Abdulaziz University, P.O. Box 80207, \\ Jeddah 21589, Saudi Arabia \\ 4 Department of Biology, Faculty of Science, King Abdulaziz University, P.O. Box 80203, Jeddah 21589, \\ Saudi Arabia; nalbourai@kau.edu.sa or nalbourae@gmail.com (N.A.A.); malgandaby@yahoo.com (M.M.A.) \\ 5 Biology Department, College of Science, Princess Nourah bint Abdulrahman University, P.O. Box 84428, \\ Riyadh 11671, Saudi Arabia \\ * Correspondence: aabdellatteff@kau.edu.sa (A.A.-L.); welaref@kau.edu.sa (W.M.A.); \\ Tel.: +966-54-6477-175 (A.A.-L.); +966-56-0352-034 (W.M.A.)
}

Academic Editors: Isabel C.F.R. Ferreira and Nancy D. Turner

Received: 12 March 2019; Accepted: 4 April 2019; Published: 8 April 2019

\begin{abstract}
Alcyonium corals are benthic animals, which live in different climatic areas, including temperate, Antarctic and sub-Antarctic waters. They were found to produce different chemical substances with molecular diversity and unique architectures. These metabolites embrace several terpenoidal classes with different functionalities. This wide array of structures supports the productivity of genus Alcyonium. Yet, majority of the reported compounds are still biologically unscreened and require substantial efforts to explore their importance. This review is an entryway to push forward the bio-investigation of this genus. It covers the era from the beginning of reporting metabolites from Alcyonium up to March 2019. Ninety-two metabolites are presented; forty-two sesquiterpenes, twenty-five diterpenes and twenty-five steroids have been reported from sixteen species.
\end{abstract}

Keywords: Alcyoniidae; mevalonates; steroids; anti-inflammatory; antimicrobial; antifeedant

\section{Introduction}

The marine environment is represented by two-thirds of the earth and epitomizes harsh parameters. It has a wide range of temperature; ranged from $-1.5^{\circ} \mathrm{C}$ to $350{ }^{\circ} \mathrm{C}$, pressure ranged from 1 to over 1000 atmosphere, light ranged from complete darkness to extensive photic zones and nutritional-rich till nutrient-spar [1-3].

Thirty-four animal phyla were taxonomically identified, however, thirty-six were found in a marine habitat. The marine species counts around 240,000 known species, albeit less than five percent of the deep sea has been explored [4,5]. Production of the unique metabolites from marine organisms could be explained by the harsh and competitive conditions. Although the terrestrial sources are providing unique bioactive metabolites, the marine organisms produce a considerable number of unprecedented bioactive substances, which have a great possibility to be a lead drug [6]. Blunt and his co-workers reported that the identified marine metabolites estimated to be 31,000 (i.e., 1000 substances per year) [7]. The molecular structures associated, particularly, produced from marine organisms, are varying from low molecular weight to complex form [8-14]. These metabolites enhance marine 
invertebrate's survival by providing chemical defense. They play a crucial role in the adaptation of the marine organisms to the physical and chemical extreme conditions. The marine metabolites interfere with receptors and enzymes of coexisting marine competitors and predators. This emphasized the hypothesis that several of those compounds could interfere with molecular targets [15-19].

Alcyonacea (Phylum, Cnidaria; class, Anthozoa; subclass, Octocorallia; order, Alcyonacea) constitutes an important group of marine invertebrates, widely distributed in the coral reefs. They are quite numerous throughout the tropical waters, mainly live in the intertidal zones on inner reefs below the stony corals [14]. They are less prone to damage or ailments from collecting and shipping than the stony corals. They protect themselves by the production of certain chemical mediators, due to the absence of skeletal defenses [3,14].

Soft corals have proven to be a biochemical warehouse for production of bioactive terpenoidal metabolites particularly, those belonging to the family, Alcyoniidae (37 genera) [3,20]. These types of metabolites show roles in protection and taxonomical identification (i.e., markers) [21]. Genus Alcyonium (Flame corals) are small soft corals. They live in colonies of polyps (round body) and forming erect fleshy masses. The absence of an internal skeleton was observed. Each polyp contains eight small, feathery tentacles called pinnates. These pinnates contain stinging cells that they utilized to catch their prey. They are micro carnivores that feed on planktonic animals. Their body is a pale yellow color, however, the stem of the polyp is orange and the polyps are bright red. Genus Alcyonium comprises 141 species, of which 71 were accepted to be transferred to other genera $[4,5,8]$.

In the current review, the isoprenoidal derivatives which, isolated from genus Alcyonium, are presented. These compounds showed certain effects on some diseases and could have a coming role in drug discovery. It is interesting to discuss the future perspectives of the chemical structures and possible biological activity relationships. Sixteen Alcyonium species of different geographical locations have been chemically investigated, resulted in the identification of ninety-two metabolites which categorized under three classes; sesquiterpenes, diterpenes and steroids. Extensive literature surveys were performed employing different scientific databases (e.g., SciFinder, Scopus, PubMed, Scholar, ScienceDirect and Web of Science), indicated the scarce or almost absence of review interested in this theme.

\section{Terpenoids from Alcyonium}

Soft corals of the genus Alcyonium are widely spread all over the oceans. Some of them were chemically and biologically investigated (Table 1, Figure 1). Up to March 2019, ninety-two terpenoidal derivatives have been isolated and identified from sixteen species of genus Alcyonium, namely, Alcyonium sp., A. antarcticum, A. coralloides, A. fauri, A. flaccidu, A. foliatum, A. gracillimum, A. grandis, A. molle, A. paessleri, A. palmatum, A. patagonicum, A. utinomii, and A. valdiviae (Table 1 and Figure 2).

Eighty-six isoprenoids have been recorded from Alcyonium for the first time, and the remaining six were previously reported from other marine sources. Sesquiterpenoids are eminent metabolites from Alcyonium, which were categorized under eleven carbo-skeleton types; aphanmalane, aromadendrane, bulgarane, cadinane, bicyclogermacrane, eudesmane, furanosesquiterene, guaiazulene illudalane, paesslerane, and triprenylhydroquinone (Figures 2 and 3). Besides, diterpenoids from Alcyonium are classified into six classes, cembrane, cladiellin, eunicellin, prenylbicyclogermacrane, xenicin, and xenicane. Finally, twenty-five steroids have been identified. Interestingly, steroids cholestane (C-27), campestane (C-28), gorgostane (C-30) along with pregnane (C21) carbon skeleton were all identified. The diversity of the terpenoidal content of genus Alcyonium is a source of 92 metabolites which categorized under 21 classes. This addressed that, the metabolites were obtained from $20 \%$ of the identified species, thus, the chem-biological investigations of the rest $(80 \%)$ are urgently required. 
Table 1. Terpenoidal metabolites isolated from genus Alcyonium.

\begin{tabular}{|c|c|c|c|c|c|}
\hline Cpd. No. & Cpd. Name & Species & Biological Effects & Class of Cpd & Ref. No. \\
\hline 1 & Guaiazulene & Alcyonium sp. & - & Guaiazulene & [22] \\
\hline 2 & (+)-Coralloidin-A & \multirow{3}{*}{ A. coralloides } & - & Eudesmane sesquiterpene & \multirow{3}{*}[23,24]{} \\
\hline 3 & (-)-Coralloidin- B & & - & Bicyclogermacrane & \\
\hline $4-6$ & Coralloidin C, D and E & & - & Eudesmane sesquiterpene & \\
\hline $7-8$ & Millecrone A and B & \multirow{2}{*}{$\begin{array}{l}\text { A. foliatum and } \\
\text { A. valdiviae }\end{array}$} & Antifungal & $\begin{array}{l}\text { Aphanmalane sesqui. } \\
\text { Aromadendrane sesqui. }\end{array}$ & [25] \\
\hline 9-10 & Millecrol A and B & & Antimicrobial & $\begin{array}{l}\text { Aphanmal sesqui. } \\
\text { Cadinane sesqui. }\end{array}$ & [26] \\
\hline 11 & Furanosesquiterpenoid & A. palmatum & Antifeedant & Furanosesquiterpene & [27] \\
\hline 12 & Rietone & \multirow{3}{*}{ A. fauri } & Anti-HIV & \multirow{3}{*}{ Triprenylhydroquinone } & \multirow{3}{*}{ [28] } \\
\hline 13 & $8^{\prime}$-Acetoxyrietoneand & & & & \\
\hline 14 & 8'-Desoxyrietone & & & & \\
\hline $15-29$ & Alcyopterosins A-O & A. paessleri & Cytotoxic & Illudalane Sesquiterpene & [29] \\
\hline $30-31$ & Paesslerins A and B & A. paessleri & - & Paesslerane sesquiterpene & {$[30]$} \\
\hline 33 & 13-Acetoxy-12-acetylalcyopterosin D & \multirow{8}{*}{ A. grandis } & \multirow{8}{*}{ Antifeedant } & \multirow{8}{*}{ Illudalane Sesquiterpene } & \multirow{8}{*}{ [31] } \\
\hline 34 & 4,12-Bis(acetyl) alcyopterosin $\mathrm{O}$ & & & & \\
\hline 35 & 12-Acetyl-13-n-butanoxyalcyopterosin D & & & & \\
\hline 36 & 12-Acetyl-4-n-butanoylalcyopterosin O & & & & \\
\hline 37 & 12-Acetylalcyopterosin D & & & & \\
\hline 38 & 12-n-Butanoylalcyopterosin D & & & & \\
\hline 39 & 13-Hydroxy alcyopterosin and & & & & \\
\hline 40 & Alcyopterosin P & & & & \\
\hline 41 & Alcyonicene & \multirow{2}{*}{ A. antarcticum } & $\begin{array}{l}\text { Feeding-deterrence and } \\
\text { ichthyotoxic }\end{array}$ & \multirow{2}{*}{ Bulgarane sesquiterpene } & \multirow{2}{*}{ [32] } \\
\hline 42 & Deacetoxyalcyonicene & & - & & \\
\hline
\end{tabular}


Table 1. Cont

\begin{tabular}{|c|c|c|c|c|c|}
\hline Cpd. No. & Cpd. Name & Species & Biological Effects & Class of Cpd & Ref. No. \\
\hline 43 & Flaccidoxide & \multirow{3}{*}{ A. flaccidum } & & \multirow{6}{*}{ Cembrane diterpene } & \multirow{3}{*}{ [33] } \\
\hline 44 & Cembrene-C & & & & \\
\hline 45 & Sarcophytol B & & & & \\
\hline 46 & Alcyonol-A & \multirow{3}{*}{ A. utinomii } & - & & \multirow{3}{*}[34]{} \\
\hline 47 & Alcyonol-B & & - & & \\
\hline 48 & Alcyonol-C & & & & \\
\hline 55 & Alcyonolide & \multirow{2}{*}{ Alcyonium sp. } & & \multirow{2}{*}{ Xenicin diterpene } & [38] \\
\hline 56 & Alcyonolide-5 & & & & [39] \\
\hline 57 & $\begin{array}{l}(1 S, 2 R, 3 S, 4 R, 5 R, 6 S, 8 E, 11 S, 12 R, 13 S, 14 S) \text {-3-Acetoxy- } \\
\text { 2,12-dibutanoyloxycladiell-8-ene-4,Il-diol }\end{array}$ & A. molle & & Cladiellin diterpene & [40] \\
\hline 58 & Patagonicol & A. patagonicum & & Eunicellin diterpene & {$[41]$} \\
\hline 59 & Valdivone A & \multirow{4}{*}{ A. valdivae } & \multirow{2}{*}{ Anti-inflammatory } & \multirow{4}{*}{ Eunicellin diterpene } & \multirow{4}{*}[42]{} \\
\hline 60 & Valdivone B & & & & \\
\hline 62 & 4-O-Methyl valdivone B & & \multirow{3}{*}{-} & & \\
\hline 63 & Dihydrovaldivone A & & & & \\
\hline 64 & Palmatol & A. palmatum & & Prenylbicyclogermacrane & [43] \\
\hline $65-66$ & Zahavin $\mathrm{A}$, and zahavin $\mathrm{B}$ & A. aureum & Cytotoxic & Xenicane diterpene & {$[44]$} \\
\hline 67 & Pukalide & A. antarticum & Feeding-deterrence & Cembrane diterpene & [45] \\
\hline
\end{tabular}


Table 1. Cont.

\begin{tabular}{|c|c|c|c|c|c|}
\hline Cpd. No. & Cpd. Name & Species & Biological Effects & Class of Cpd & Ref. No. \\
\hline 68 & Gorgosterol & A. molle & & Gorgosterol & [40] \\
\hline 69 & 24-Methylenecholest-5-ene- $3 \beta, 16 \beta$-diol-3-O- $\alpha$-L-fucoside & \multirow{5}{*}{ Alcyonium sp. } & & \multirow{4}{*}{ Campestane } & \multirow{4}{*}{ [46] } \\
\hline 70 & 24-Methylenecholest-5-ene-3 $\beta, 7 \beta, 16 \beta$-triol-3-O- $\alpha$-L-fucopyranoside & & & & \\
\hline 71 & 24-Methylenecholest-5-ene-3 $\beta, 7 \alpha, 16 \beta$-triol-3-O- $\alpha$-L-fucopyranoside & & - & & \\
\hline 72 & $3 \beta, 7 \beta$-Dihydroxy-24-methylenecholesterol & & & & \\
\hline 73 & $3 \alpha, 7 \alpha, 12 \alpha$-Triacetoxy- $5 \beta$-cholanic acid & & & Cholestane & [47] \\
\hline 74 & Pregnedioside-A & \multirow{5}{*}{ Alcyonium sp. } & & \multirow{5}{*}{ Pregnane } & \multirow{5}{*}{ [48] } \\
\hline 75 & 4'-O-Acetyl-pregnedioside-A & & & & \\
\hline 76 & 3'-O-Acetyl-pregnedioside-A & & & & \\
\hline 77 & Pregnedioside-B & & & & \\
\hline 78 & 4'-O-Acetyl-pregnedioside & & & & \\
\hline 79 & 3-Methoxy-19-norpregna-1,3,5(10),20-tetraene & \multirow{4}{*}{ A. gracillimum } & \multirow{4}{*}{ Antifoulants } & \multirow{2}{*}{ Pregnane } & \multirow{4}{*}{ [49] } \\
\hline 80 & $\begin{array}{l}\text { 3-(4-O-Acetyl-6-deoxy- } \beta \text {-galactopyranosyloxy)-19-nor-pregna- } \\
\qquad 1,3,5(10), 20 \text {-tetraene }\end{array}$ & & & & \\
\hline 81 & 22,23-Dihydroxycholesta-1,24-dien-3-one & & & \multirow{2}{*}{ Cholestane } & \\
\hline 82 & methyl Methyl-3-oxochola-1,4,22-trien-24-oate & & & & \\
\hline 83 & 24-Methylenecholest 4-ene-3 $\beta, 6 \beta$-diol & A. patagonicum & Cytotoxic & Campestane & [41] \\
\hline 84 & Pregnenolone & \multirow{2}{*}{ A. antarticum } & \multirow{3}{*}{-} & \multirow{2}{*}{ Pregnane } & \multirow{2}{*}{ [32] } \\
\hline 85 & Pregnenolone-3-acetate & & & & \\
\hline 86 & Furospirostan & \multirow{6}{*}{ A. gracillimum } & & \multirow{4}{*}{ Cholestane } & \multirow{6}{*}{ [50] } \\
\hline $87-88$ & Cholestane derivative with hemiketal functionality & & Cytotoxic & & \\
\hline 89 & Steroid with unusual dihydropyran ring & & & & \\
\hline 90 & Ketosteroidal derivatives & & - & & \\
\hline 91 & Pregnadienone & & & \multirow[t]{2}{*}{ Pregnane } & \\
\hline 92 & Pregnenone & & - & & \\
\hline
\end{tabular}




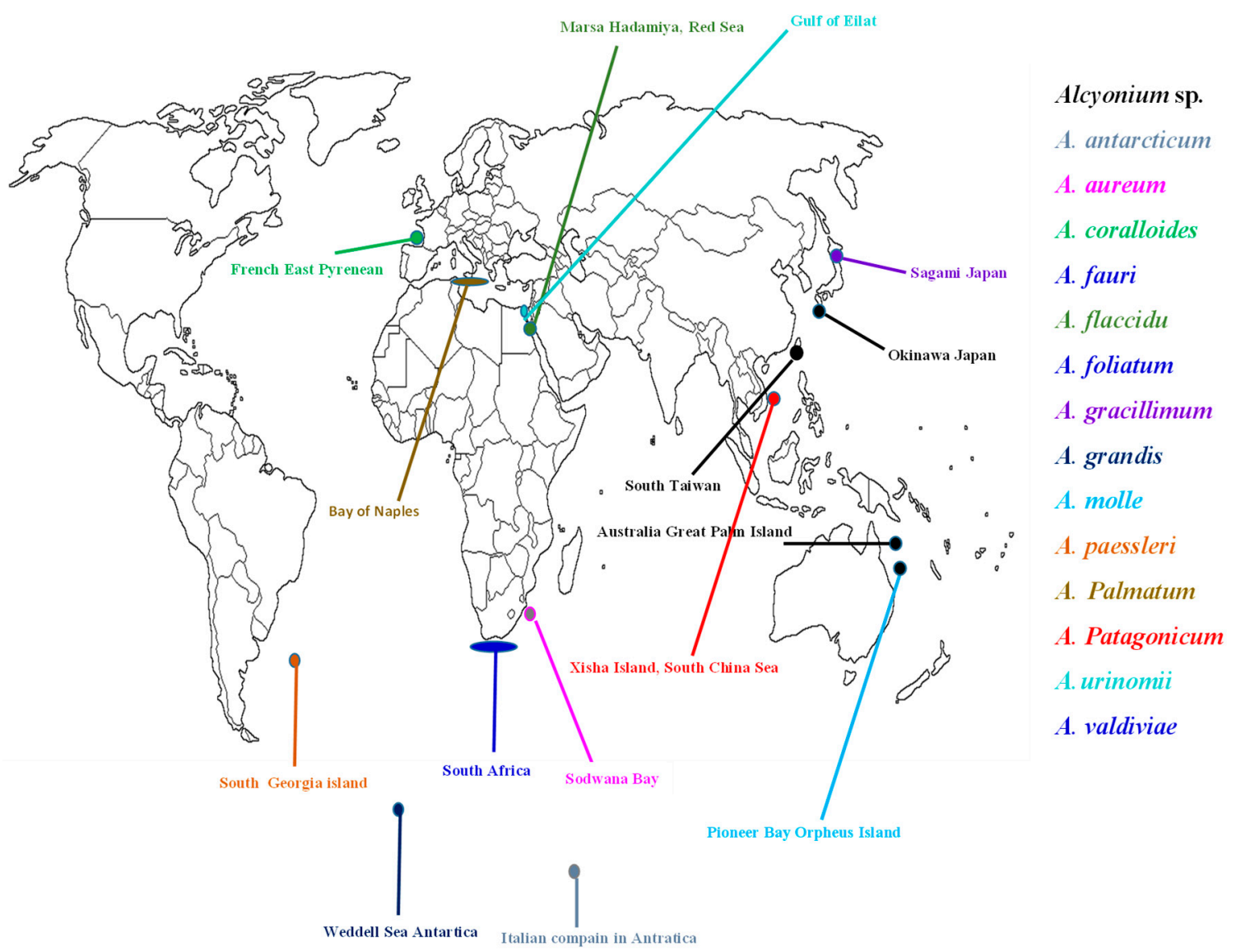

Figure 1. Locations of the investigated Alcyonium species.

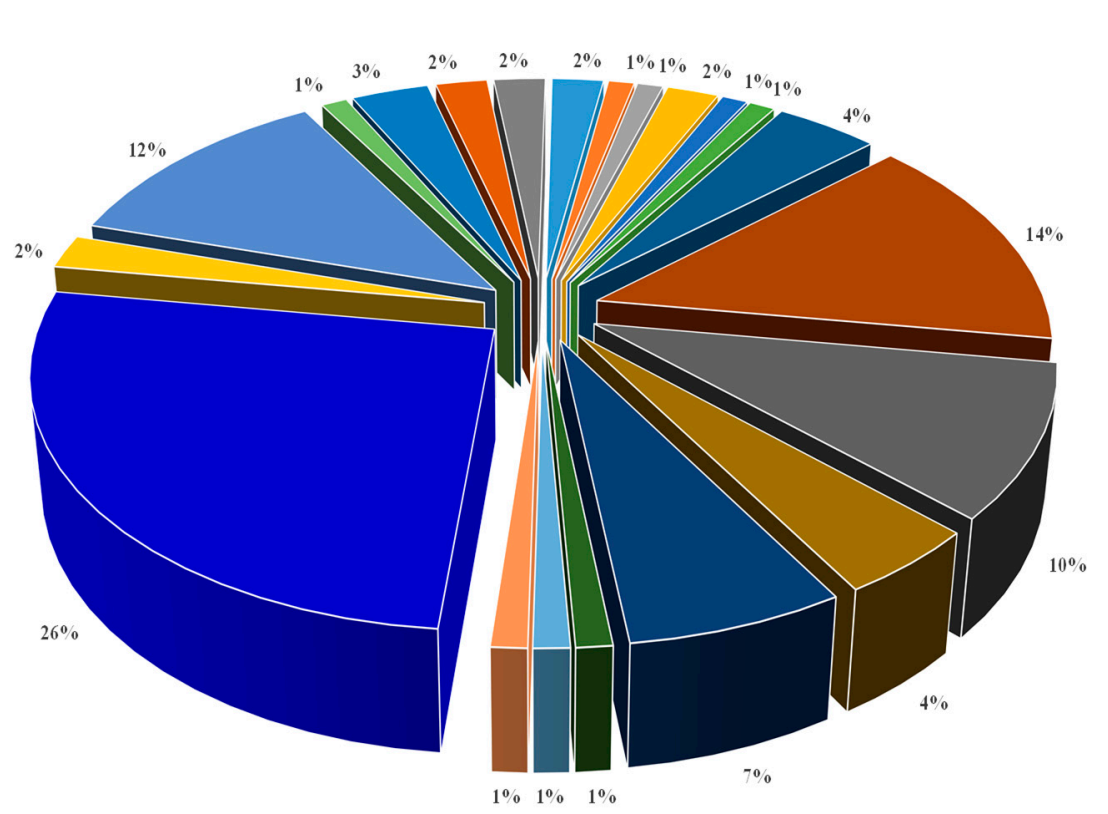

- Aphanmalane
- Aromadendrane
- Bicyclogermacrane
- Bulgarane
- Cadinane
- Caldiellin
- Campestane
- Cembrane
- Cholestane
- Eudesmane
- Eunicellin
- Furanosesquiterene
- Gorgostane
- Guaiazulane
- Illudalane
" Paesslerane
- Pregnane
- Prenylbicyclogermacrane
- Triprenylhydroquinone
" Xenicane
- Xenicin

Figure 2. Percentage of chemical classes of Alcynocium terpenoids. 
<smiles>CCCc1c(C)cc2c(c1C)CC(C)(C)C2</smiles>

Eudesmane

Illudalane<smiles>CC(C)CCCC(C)CCCC(C)CCC1=CC(O)C=CC1O</smiles>

Triprenylhydroquinone

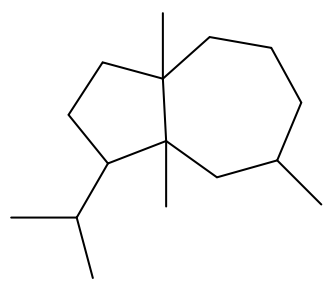

Aphnamalane
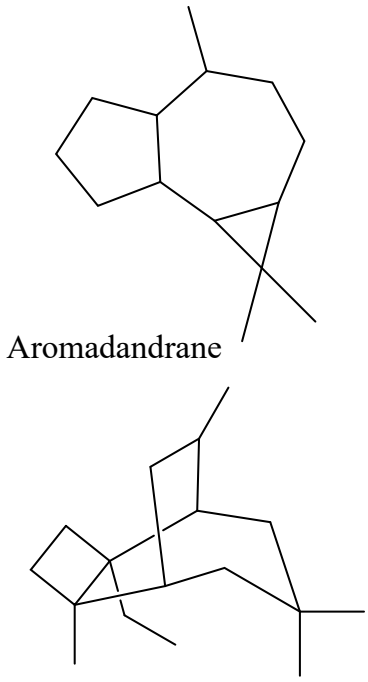

Passelerane<smiles>CC1CCC2C(C)CCC(C(C)C)C2C1</smiles>

Bulgarane<smiles>CC1=C2C=CC(C)C2C=C(C(C)C)C=C1</smiles>

Guaiazulene

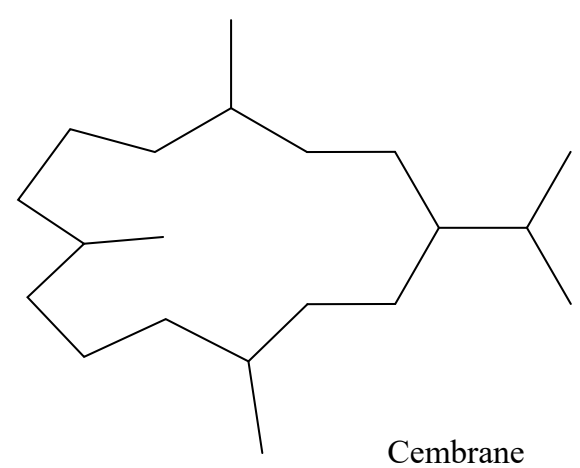

Cembrane

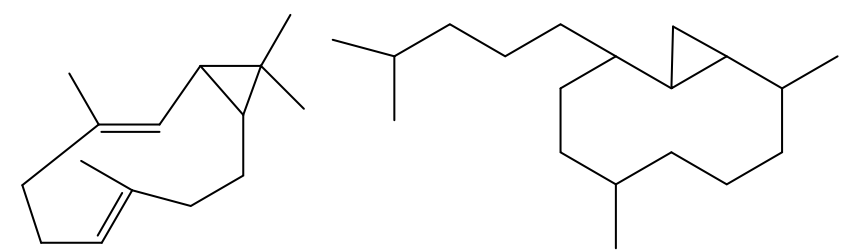<smiles>CC1CCCC(C)C2OC3CC(C)CCC(C(C)C)C3C2C(C)C1</smiles>

Eunicellin
Prenylbicyclogermacrane

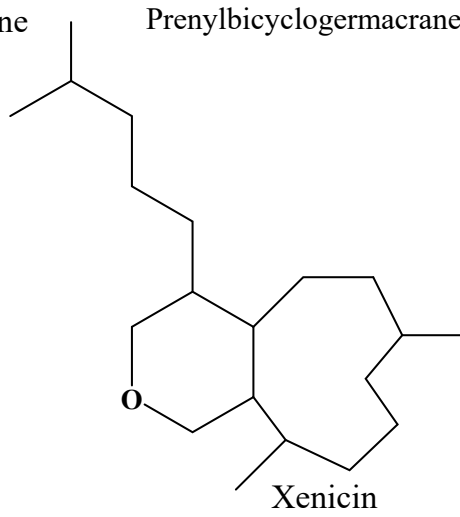

Figure 3. Selected chemical structures of Alcyonium terpenoidal classes.

\subsection{Sesquiterpenes}

The chemical diversity of the aforementioned sesquiterpenoidal classes emphases the importance of genus Alcyonium as a potential source of novel metabolites. A bicyclic sesquiterpenoidal, guaiazulene (1), a pigment obtained from Alcyonium sp., which was collected from the North East Bay, Great Palm Island of Australia. It was used as a taxonomical marker for the gorgonian soft coral [22]. Chemical investigation of the Mediterranean A. coralloides, collected from the French East Pyrenean, yielded two novel sesquiterpenes (+)-coralloidin-A (2), and (-)-coralloidin-B (3) (Figure 4 and Table 1) [23]. Novel eudesmane sesquiterpenes, coralloidin C, D and E (4-6) have been identified from the same species. The absolute stereochemistry of 4 was estimated by application of the exciton-coupling method and confirmed by interpretation of the negative and positive cotton effects after measuring the Circular Dichroism spectra [24]. 


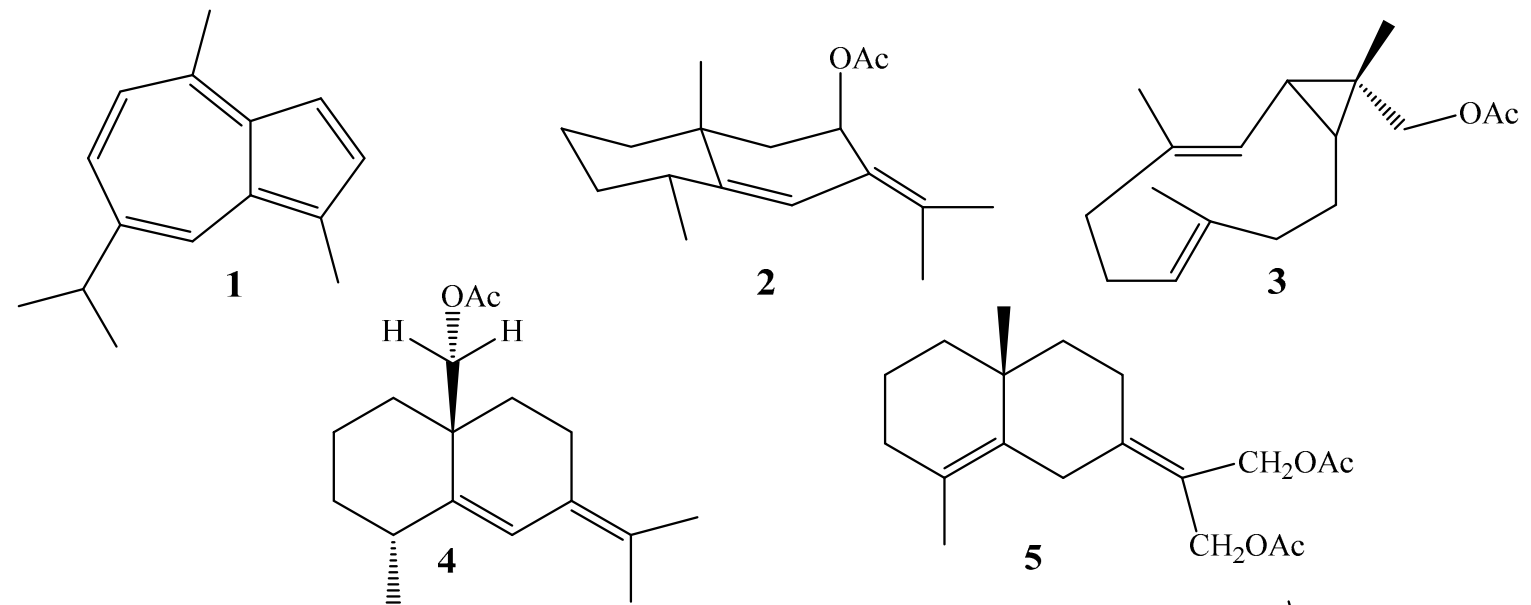<smiles>C[C@H]1CCC[C@]2(C)CC=C(C(C)(C)O)C=C12</smiles><smiles>C=C1CCC[C@]2(C)CC[C@H](C(C)C)[C@H]2C1=O</smiles><smiles>[CH][C@@]12C(=C(C)C(=O)C[C@H]3[C@@H]1C3(C)C)CC[C@@H]2C</smiles><smiles>C=C1CCC[C@]2(C)CC[C@H](C(C)C)[C@H]2[C@H]1O</smiles><smiles>C=C1CC[C@@H]2[C@H](C1)[C@@](C)(O)CC[C@@H]2C(C)C</smiles><smiles>C=CC(=C)CC/C=C(\C)Cc1cc(C)co1</smiles>

Figure 4. Chemical structures of compounds 1-11.

A south African nudibranch, Leminda millecra, was investigated chemically and led to the isolation of four novel aromadendrane and aphnamalane, namely, millecrone A and B (7 and 8), and millecrol A and B (9 and 10). It was surprising that the same metabolites were obtained from the organic extract of spicules in the dissected digestive glands of the soft corals $A$. foliatum and A. valdiviae $[25,26]$. Although millecrone B (8) was inactive against the growth of Candida albicans mellicrone A showed inhibition at $50 \mathrm{~g} /$ disk; while millecrol A and B (9 and 10) showed antimicrobial activity against Staphylococcus aureus and Bacillus subtilis $[25,26]$.

As known, furanosesquiterpenoid (11) has been identified from the bay of Naples octocoral A. palmatum. This compound and its congeners (e.g., 2,4-disubstituted furanosesquiterpene) play a role in the taxonomy of the Alcyonacea order [27].

A. fauri is an endemic southern Africa soft coral, has been investigated and yielded three sesquiterpene hydroquinones, rietone (12), $8^{\prime}$-acetoxyrietone (13) and $8^{\prime}$-desoxyrietone (14) [28]. The NCI's CEM-SS cell line assay was designed to evaluate the metabolites which have effect at any stage of HIV virus reproductive cycle and fortunately, rietone (12) showed moderate effect. It was remarkable that A. fauri collected during this study was found growing on living Hadromerida sponges (Tethya species) and certain study has been done indicated that there is no chemical affinities or similarity between A. fauri and sponge or other soft coral, regarding the production of metabolites [28].

Fifteen rare illudalane sesquiterpenes (Figure 5); alcyopterosins A-O (15-29) had been isolated from sub-Antarctic soft coral A. paessleri, collected from the South Georogia Islands, eight out of fifteen compounds have a nitrate ester group $(\mathbf{1 6}, \mathbf{1 7}, \mathbf{1 9 - 2 2 ,} 24$ and $\mathbf{2 7})$, while four compounds are chlorinated 
$(\mathbf{1 5}, \mathbf{1 8}, 26$ and 26) [29]. These metabolites were the first illudalane sesquiterpenoidal derivatives, which were reported from marine organisms. The stereochemistry of the alcyopterosins showed a different configuration of the hydroxylated position (C-10). Compound 22 was levorotatory while 23 and 27 were dextrorotatory. The absolute stereochemistry was established by the implementation of the modified Mosher method led to the establishment of the chemical structures of 23, 26, and 27 had $10 S$ configuration, while 22 was $10 R$. Compound 19 showed mild cytotoxicity against Hep-2 (human larynx carcinoma) cell line ( $\mathrm{IC}_{50} 13.5 \mu \mathrm{M}$ ), while compounds 15, 17, and 22 were cytotoxic against HT-29 (human colon carcinoma) at $10 \mu \mathrm{g} / \mathrm{mL}$. Further investigation of the same USA group and marine organisms led to the identification of two novel tricyclic sesquiterpenoids, paesslerins $A$ and B (30-31) [30].<smiles>[R]CCc1c(C)cc2c(c1C[R])CC(C)(C)C2([R3])[R]</smiles>

$22 \mathrm{R}_{1}=\mathrm{ONO}_{2} \quad \mathrm{R}_{2}=\mathrm{H} \quad \mathrm{R}_{3}=\mathrm{OH} \quad \mathrm{R}_{4}=\mathrm{H}$

$25 \quad \mathrm{R}_{1}=\mathrm{Cl} \quad \mathrm{R}_{2}=\mathrm{OH} \quad \mathrm{R}_{3}=\mathrm{H} \quad \mathrm{R}_{4}=\mathrm{OH}$

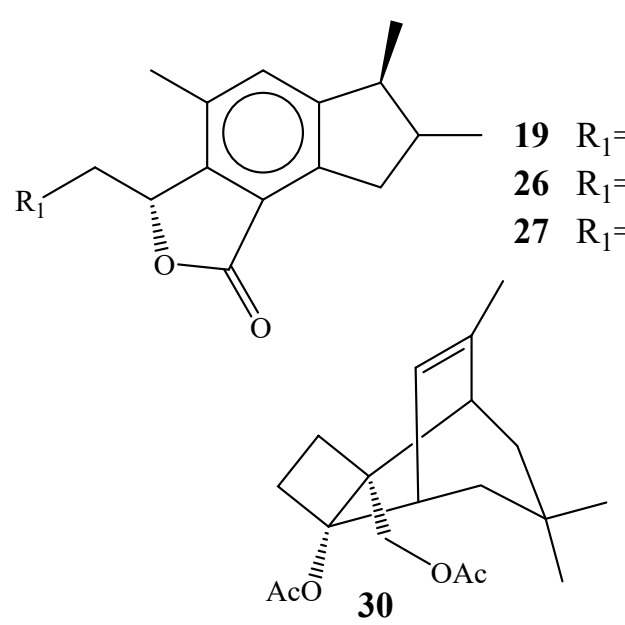

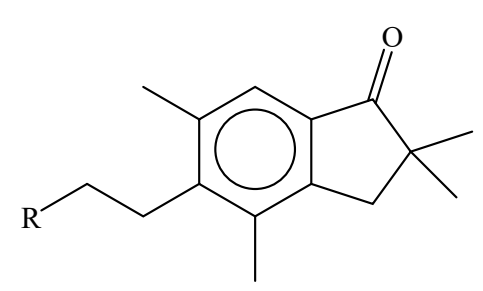

$17 \mathrm{R}=\mathrm{ONO}_{2}$

$24 \mathrm{R}=\mathrm{ONO}_{2}$

$28 \mathrm{R}=\mathrm{OH}$<smiles>[R]CCc1c(C)cc2c(c1C[R])CC(C)(C)C2</smiles>

$15 \mathrm{R}_{1}=\mathrm{Cl} \quad \mathrm{R}_{2}=\mathrm{H}$

$16 \mathrm{R}_{1}=\mathrm{ONO}_{2} \quad \mathrm{R}_{2}=\mathrm{H}$

$18 \mathrm{R}_{1}=\mathrm{Cl} \quad \mathrm{R}_{2}=\mathrm{OH}$

$21 \mathrm{R}_{1}=\mathrm{ONO}_{2} \mathrm{R}_{2}=\mathrm{OH}$

$29 \mathrm{R}_{1}=\mathrm{OH} \quad \mathrm{R}_{2}=\mathrm{OH}$

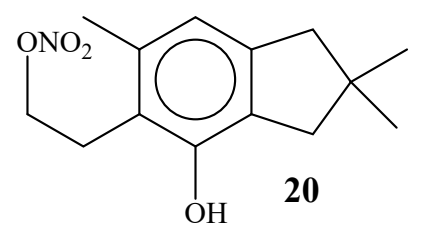

Figure 5. Chemical structures of compounds 12-31.

Lipophilic extract of the Antartic A. grandis, collected from Weddell Sea, Antartica yielded nine unreported sesquiterpenoids, 4,12-bis- $n$-butanoylalcyopterosin $O$ (32), 13-acetoxy-12-acetyl alcyopterosin D (33) (Figure 6), 4,12-bis(acetyl) alcyopterosin O (34), 12-acetyl-13- $n$-butanoxy alcyopterosin D (35), 12-acetyl-4- $n$-butanoylalcyopterosin O (36), 12-acetylalcyopterosin D (37), 12-n-butanoylalcyopterosin D (38), 13-hydroxy alcyopterosin (39) and alcyopterosin P (40). The lipophilic extract exhibited a feeding-deterrent effect towards the Antarctic predator Odontaster validus and proved to have a potent repellent effect [31]. 
<smiles>[R20]CCc1c(C)cc2c(c1C[R20])CC(C)(C)C2</smiles>

$32 \mathrm{R}_{1}=\mathrm{COCH}_{2} \mathrm{CH}_{2} \mathrm{CH}_{3} \quad \mathrm{R}_{2}=\mathrm{COCH}_{2} \mathrm{CH}_{2} \mathrm{CH}_{3}$

$34 \mathrm{R}_{1}=\mathrm{COCH}_{3} \quad \mathrm{R}_{2}=\mathrm{COCH}_{3}$

$36 \mathrm{R}_{1}=\mathrm{COCH}_{3}$<smiles>[R20]Cc1cc2c(c(CCCl)c1CO[R20])CC(C)(C)C2</smiles>

$33 \mathrm{R}_{1}=\mathrm{COCH}_{3} \quad \mathrm{R}_{2}=\mathrm{COCH}_{3}$

$35 \mathrm{R}_{1}=\mathrm{COCH}_{3} \quad \mathrm{R}_{2}=\mathrm{COCH}_{2} \mathrm{CH}_{2} \mathrm{CH}_{3}$

$39 \mathrm{R}_{1}=\mathrm{R}_{2}=\mathrm{H}$<smiles>Cc1cc2c(c(CO)c1CCCl)C[C@](C)(CCl)C2</smiles>

$37 \mathrm{R}=\mathrm{COCH}_{3}$

$38 \mathrm{R}=\mathrm{COCH}_{2} \mathrm{CH}_{2} \mathrm{CH}_{3}$
40<smiles>CCc1c(C)cc2c3c1C(=O)O[C@H]3C(C)(C)C2</smiles>

$41 \mathrm{R}=\mathrm{OCOCH}_{3}$

$42 \mathrm{R}=\mathrm{H}$<smiles>[2H][C@@H]1C[C@H](C)C[C@@H]2[C@@H](C(=C)C)CC[C@@H](C(=C)C)[C@@H]21</smiles>

Figure 6. Chemical structures of compounds 31-42.

A. antarcticum, collected during the XVII Italian campaign in Antarctica off Terra Nova Bay [31], yielded a rare bulgarane sesquiterpene; alcyonicene (41), deacetoxyalcyonicene (42), and 4-methyl-2-[(E)-2-methyl-6-methyleneocta-2,7-dienyl]-furan (11) [32]. Feeding-deterrence and ichthyotoxic effects of alcyonicene (41), as well as 4-methyl-2-[(E)-2-methyl-6-methyleneocta-2,7-dienyl] -furan were preliminarily evaluated by conducting assays with Carassius auratus and Gambusia affinis [32].

\subsection{Diterpenes}

A cembranoid-type diterpene, 11,12-epoxy-13-hydroxy-14-acetoxycembrene-C (Flaccidoxide, 43) (Figure 7), was reported for the first time from A. flaccidum, along with known cembranoids, cembrene-C (44) and sarcophytol-B (45). This species was collected from Marsa-Hadamiya (Gulf of Suez, Red Sea) [33].

Examination of A. utinomii, was collected from the Gulf of Suze, led to the isolation of three cembranoidal derivatives with the same molecular weight, alcyonol-A (46), alcyonol-B (47), and alcyonol-C (48). The difference between the chemical structure of compounds 46 and 47 is mainly in the location of the hydroxyl group [34].

D' Ambrosio et al. reported two new cembranoidal metabolites, coralloidolide A (49) \& B (50) with peculiar structure from the French East Pyrenean of the Mediterranean Sea A. coralloides (Figure 8). The two structures are peculiar with a rare (7Z)-configuration. This feature is rare in cembranoids [35]. A study from the same group reported three novel metabolites; 3,7-cyclized cembranoid (Coralloidolide C, 51), O-bridged diketonic cembranolide (Coralloidolide D, 52) and diketonic epoxycembranolide (coralloidolide E, 53) [36]. Further investigation of the same species and same group led to reporting of the first example of 2, 6-cyclized cembranolide (Coralloidolide F, 54) [37]. 

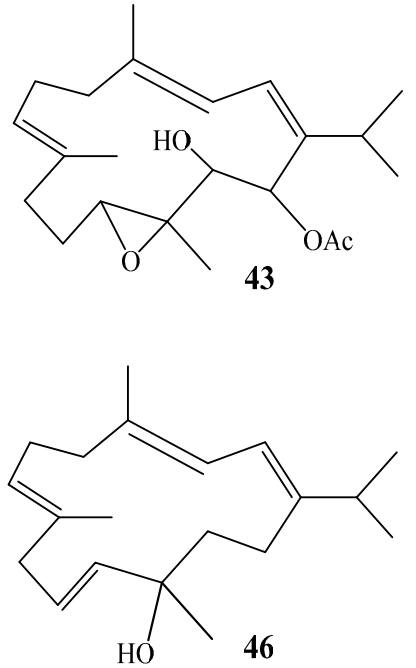

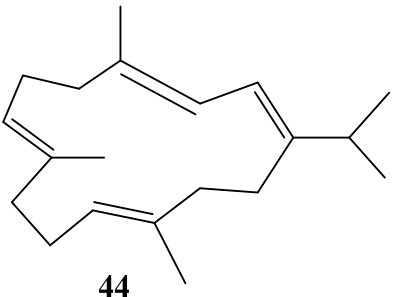

44

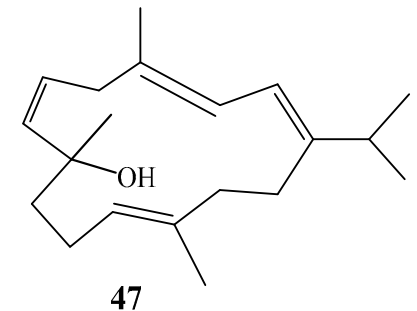

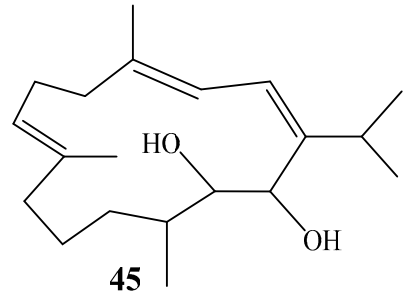

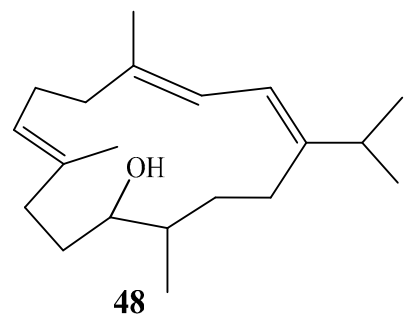

Figure 7. Chemical structures of compounds 43-48.
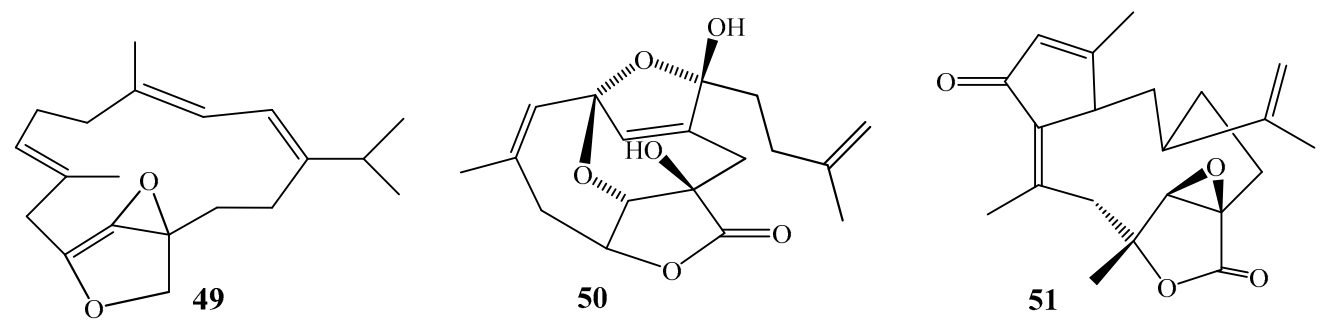

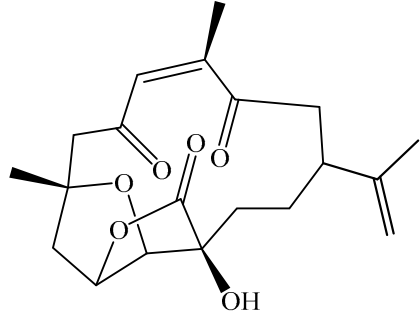

52

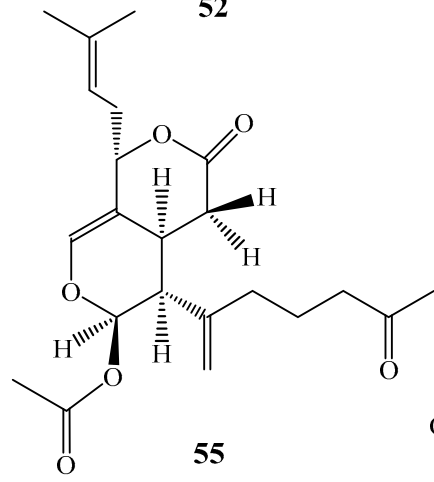

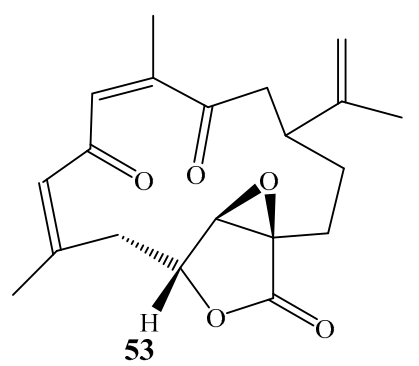

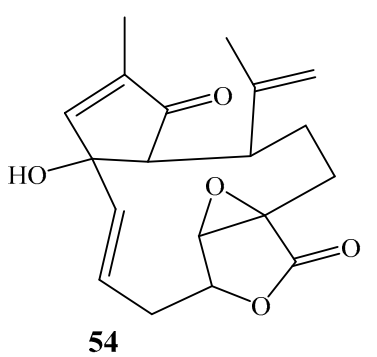

54

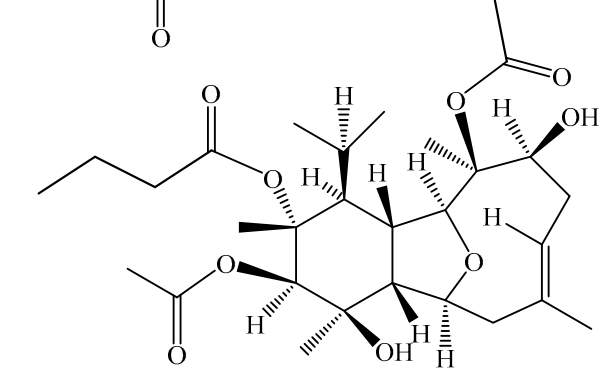

57

Figure 8. Chemical structures of compounds 49-57. 
Alcyonolide (55) is an unusual diterpenoidal acetate, was isolated from an Okinawan soft coral Alcyonium sp. [38]. Alcyonolide-5 (56) is a triacetate derivative, obtained from Alcyonium sp. collected from Lamont Reef in the Capricorn Bunker group [39]. These metabolites were believed to be derived from a xenicin-type precursor.

A cladiellin-based diterpene $(1 S, 2 R, 3 S, 4 R, 5 R, 6 S, 8 E, 11 S, 12 R, 13 S, 14 S)$-3-acetoxy-2,12-dibutanoyl oxycladiell-8-ene-4,11-diol (57) has been reported from A. molle, collected at Pioneer Bay, Orpheus Island. Its absolute configuration was based on the kinetic resolution method of Horeau [40].

Patagonicol (58) (Figure 9), a new diterpene of eunicellin skeleton has been reported from the Soft coral A. patagonicum collected from the Xisha islands off the south China Sea. Its structure was confirmed by X-ray diffraction [41].

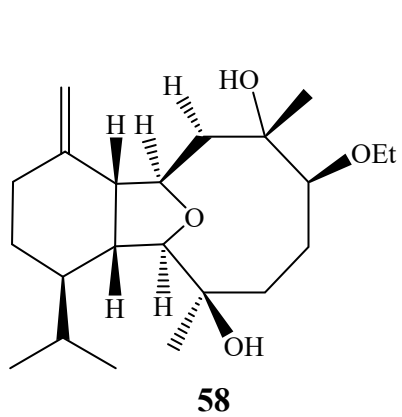<smiles>CC(C)=CC(C)OC1CC2C(C)=CC(=O)C(C(C)C)C2/C=C(/C)C2(O)C=CC1(C)O2</smiles><smiles>CC1=CC(=O)C(C(C)C)C2/C=C(\C)C3(O)C=CC(C)(O3)C(OC(=O)Cc3ccccc3)CC12</smiles><smiles>COC12C=CC(C)(O1)C(OC(=O)C=C(C)C)CC1C(C)=CC(=O)C(C(C)C)C1C=C2C</smiles><smiles>COC12C=CC(C)(O1)C(OC(=O)Cc1ccccc1)CC1C(C)=CC(=O)C(C(C)C)C1/C=C\2C</smiles><smiles>C=CC=CC</smiles>

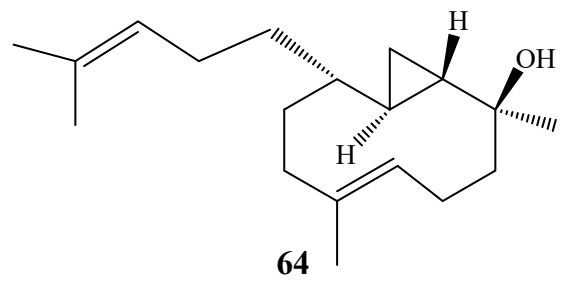

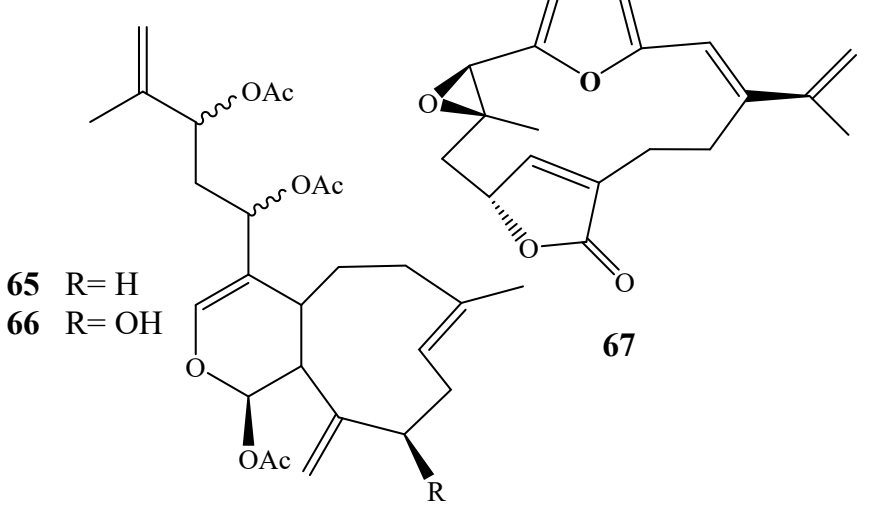

Figure 9. Chemical structures of compounds 58-67.

The soft coral A. valdivae, collected from Coffee Bay, Transkei, South Africa, yielded five diterpene esters, valdivone A (59), valdivone B (60), 4-O-methyl valdivone A (61), 4-O-methyl valdivone B (62) and dihydrovaldivone $\mathrm{A}$ (63). Carbon skeleton of valdivones is eunicellin-type which closely related to sarcodictyins. The difference between them is the location of the ether ring however they produced by different soft corals (i.e., A. valdivae (order Alcyonacea) and Sarcodictyon roseum (order Stolonifera)). Valdivones A (59) and B (60) show strong inhibition of chemically-induced inflammation in the mouse 
ear assay, however, no inhibition on the bee venom phospholipase A. Finally, the valdivones showed no effect against a standard panel of bacteria and fungi [42].

A diterpene of the prenylbicyclogermacrane skeleton wasn't widely occurred among marine organisms. Fortunately, A. palmatum was collected from Mazara de1 Vallo (West Sicily), led to the isolation of palmatol (64). Palmatol showed toxicity against Gumbosia offinis as well as cytotoxic against brine shrimp (Artemia salina) [43].

Xenicane-type diterpenoid was reported from Alcyonium, for instance, zahavin A (65), and zahavin $\mathrm{B}$ (66), were isolated from a specimen of $A$. aureum, which collected at depth more than $28 \mathrm{~m}$ at Sodwane Bay, South Africa. The two compounds showed a cytotoxic effect against P-388 mouse leukemia, A-549 human lung carcinoma, MEL-28 human melanoma, and HT-29 human colon carcinoma [44].

Pukalide (67) has been reported from soft coral $A$. antarticum, which was collected during the XVII Italian campaign in Antartica off Terra Nova Bay [32]. It is a known diterpene, which was previously reported from Sinularia abrupta. Pukalide showed feeding-deterrence against Carassius auratus at a concentration of $50 \mu \mathrm{g} / \mathrm{mL}[32,45]$.

\subsection{Steroids}

Gorgosterol (68) has been reported from A. molle, collected at Pioneer Bay, Orpheus Island. Its structure was elucidated based on ${ }^{\mathrm{I}} \mathrm{H}-\mathrm{NMR}$ spectral data and other physical properties [40].

Investigation of Alcyonium sp., which, was collected from the Andaman and Nicobar coasts, led to identification of three new polyhydroxysterol gyclosides, 24-methylenecholest-5-ene-3 $\beta$, 16 $\beta$-diol-3-O- $\alpha$-L-fucoside (69) (Figure 10), 24-methylenecholest-5-ene-3 $\beta, 7 \beta, 16 \beta$-diol-3-O- $\alpha$-Lfucopyranoside (70), and 24-methylenecholest-5-ene-3 $\beta, 7 \alpha, 16 \beta$-triol-3-O- $\alpha$-L-fucopyranoside (71), along with the already reported polyhydroxy sterol $3 \beta, 7 \beta$-dihydroxy-24-methylenecholesterol (72). These compounds play an important role in the chemotaxonomical approach since they are rare in such soft coral [46].

A soft coral, Alcyonium sp., which was collected from the coast of southern Taiwan and found to produce $3 \alpha, 7 \alpha, 12 \alpha$-triacetoxy-5 $\beta$-cholanic acid (73). Its structure was assigned on the basis of spectroscopical data and its configuration was further supported by molecular mechanics calculations [47].

The acetone extract of Alcyonium sp., which was collected from Taketomijima, Okinawa, yielded rare five steroidal glycosides of pregnene-type (Pregnedioside-A, 74), 4'-O-acetyl-pregnedioside-A (75), 3'-O-acetyl-pregnedioside-A (76), pregnedioside-B (77) and $4^{\prime}$-O-acetyl-pregnedioside (78). This was the first report of these steroidal compounds reported as glyco-conjugates from marine organisms [48].

Four new steroid derivatives 3-methoxy-19-norpregna-1,3,5(10),20-tetraene (79), 3-(4-O-acetyl6-deoxy- $\beta$-galactopyranosyloxy)-19-norpregna-1,3,5(10),20-tetraene (80), 22,23-dihydroxy cholesta1,24-dien-3-one (81), and methyl 3-oxochola-1,4,22-trien-24-oate (82) were isolated from A. gracillimum, which was collected from the Gulf of Sagami, Japan. The new steroids (79-82) were lethal to cyprids of barnacle (Balanus amphitrite) larvae, at $100 \mu \mathrm{g} / \mathrm{mL}$, albeit showed no inhibition of larval settlement of B. amphitrite at $50 \mu \mathrm{g} / \mathrm{mL}$ [49].

A dihydroxy sterol, 24-methylenecholest 4-ene-3 $\beta, 6 \beta$-diol (83) (Figure 11), has been isolated from A. patagonicum, which was collected from the south China Sea. It had cytotoxic against the P-388 cell line [32].

Two well-known steroids, pregnenolone (84) and pregnenolone-3-acetate (85), have been isolated from the soft coral, A. antarticum, which was collected during the XVII Italian campaign in Antartica off Terra Nova Bay [31]. Seven steroids, five of which, were new steroids; furospirostan class with spiroketal functionality (86), two steroids with hemiketal functionality (87-88), steroid with unusual dihydropyran ring (89) and a steroidal ketoic derivatives (90) have been reported for the first time from A. gracillimum and already two known steroids of pregnane class pregnadienone and pregnenone (91-92). Interestingly, the crude extract of $A$. gracillimum exhibited moderate cytotoxicity $\left(\mathrm{IC}_{50}\right.$ $22.4 \mu \mathrm{g} / \mathrm{mL}$ ) and antiviral activity ( $\left.\mathrm{IC}_{50} 7.8 \mu \mathrm{g} / \mathrm{mL}\right)$ against P388 and HSV-I, respectively. Compounds 
(87-88) exhibited moderate inhibition against human cytomegalovirus $\left(\mathrm{IC}_{50} 3.7\right.$ and $7.2 \mu \mathrm{g} / \mathrm{mL}$, respectively) [50].

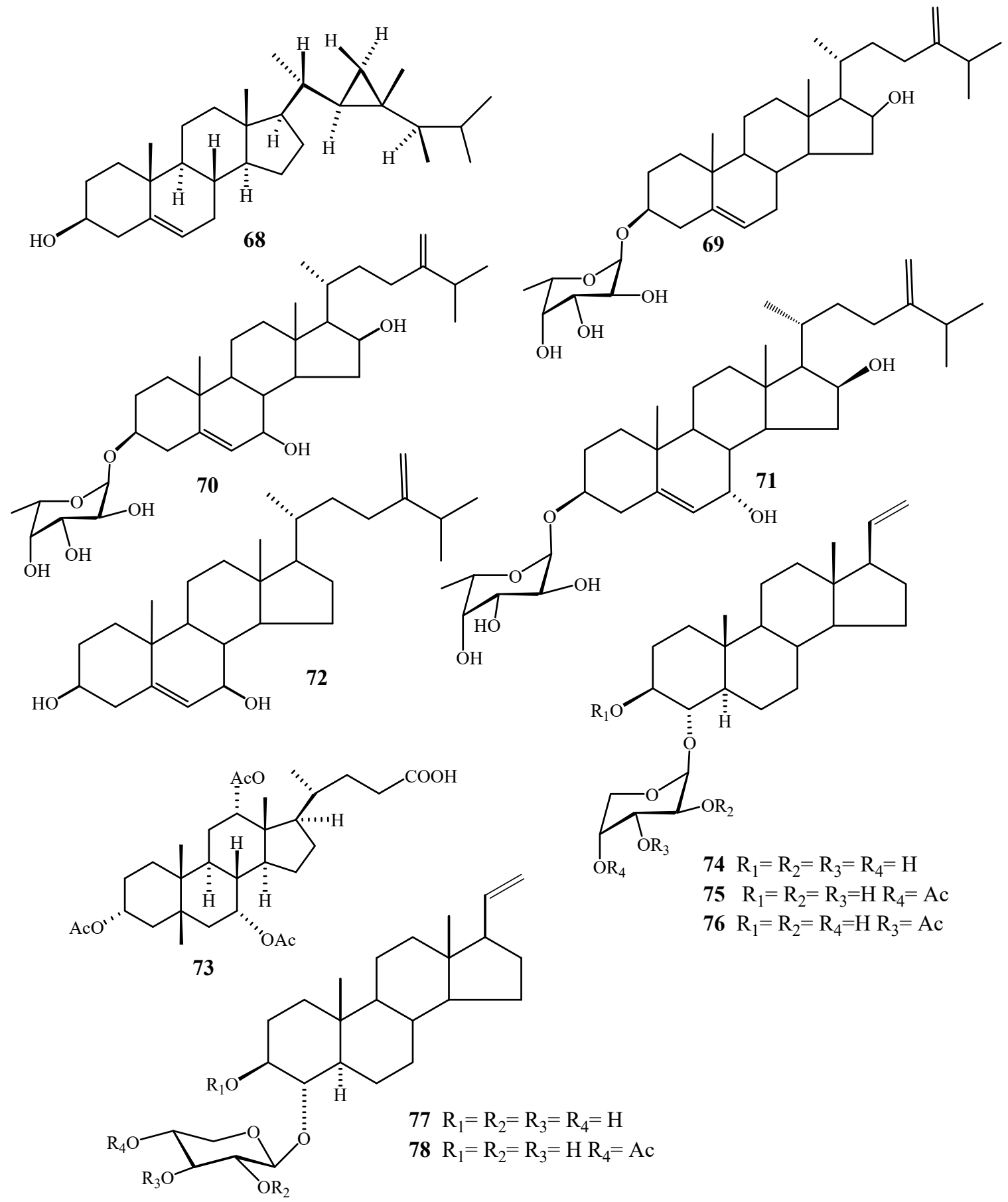

Figure 10. Chemical structures of compounds 68-78. 


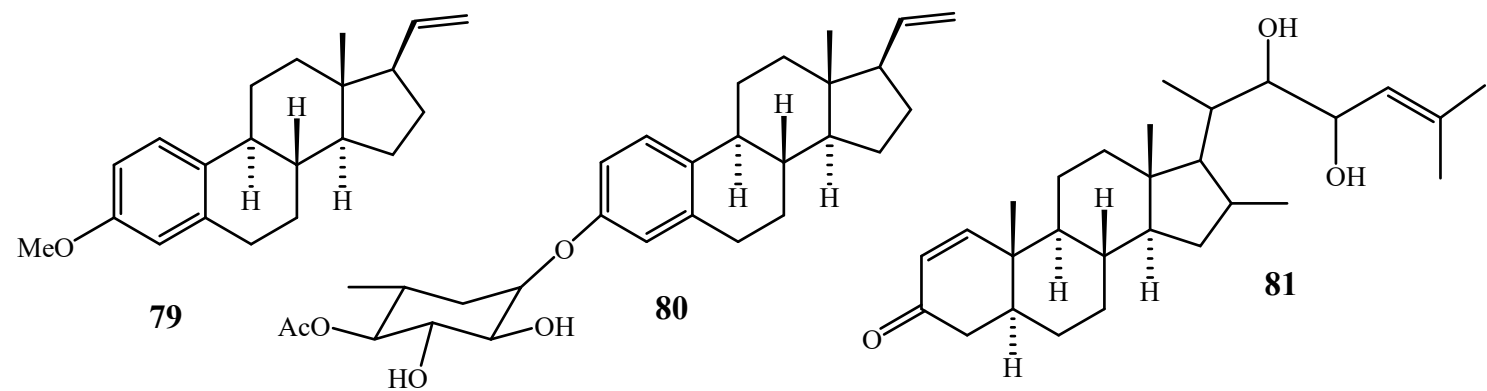

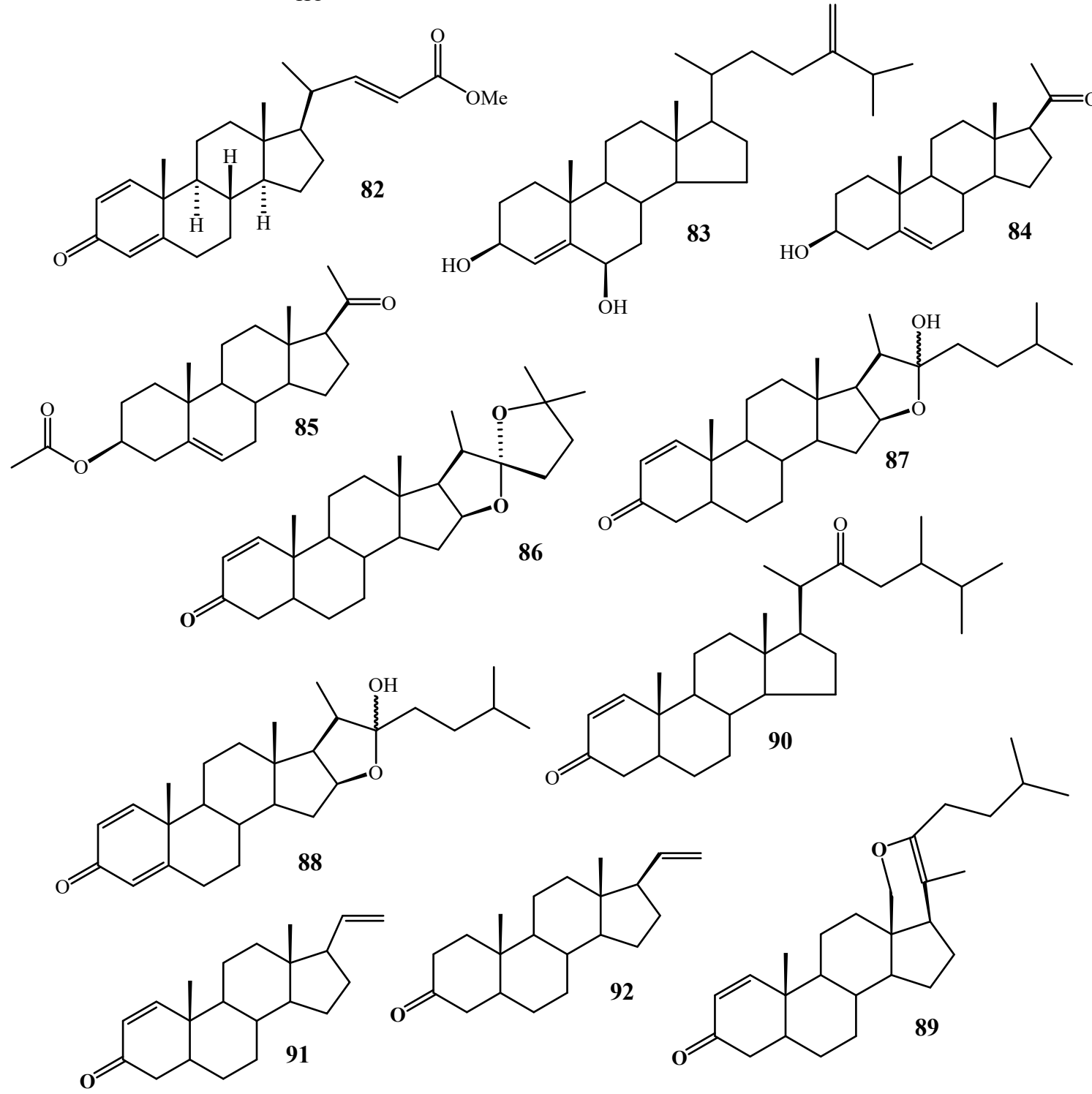

Figure 11. Chemical structures of compounds 79-92.

\section{Alcyonium Terpenoids; Current State and Future Aspect}

Terpenes are secondary metabolites, mainly derived from the five carbo-skeleton isoprene unit [51]. Derivatization or modifications of these units resulted in a diversity of molecular structures with unlimited chemical and biological characters. Up-to-date huge marine terpenoidal derivatives were reported from invertebrates, particularly, soft corals with interesting structures. Since discovering of marine terpenoids in the 1970s, several reviews devoted to describing the diversity of their chemical structures; monoterpenoids, diterpenoids, sesterterpenes, triterpenoid oligoglycosides and 
sterols [52-71]. These publications described the importance and features of chemically mediated interactions among marine organism and their role as a defense mechanism [61-71].

As aforementioned there are diversity of terpenoidal classes are presented; sesquiterpenoids (aphanmalane, aromadendrane, bulgarane, cadinane, bicyclogermacrane, eudesmane, furanosesquiterene, guaiazulene illudalane, paesslerane, and triprenylhydroquinone); diterpenoids (cembrane, cladiellin, eunicellin, prenylbicyclogermacrane, xenicin, and xenicane); and steroids (cholestane (C-27), campestane (C-28), gorgostane (C-30) along with pregnane (C21)). Unfortunately, the reported alcyonacean metabolites are still biologically unscreened. For instance, thirteen macrocyclic 'cembranoid' diterpenes $(\mathbf{4 3 - 5 4 , 6 7 )}$ urgently require substantial examination. Other cembranoidal derivatives with similar features showed an important finger-print in terms of pharmacological applications, which embrace antimicrobial, anti-proliferative, and anti-inflammatory properties [72-81]

It is wealthy to highlight the fact, which is presented in Table 1, that eight out of 42 sesquiterpenes, 20 out of 25 diterpenes and 18 out of 25 steroids were biologically unscreened. This indicated that $50 \%$ of the isolated compounds from genus Alcyonium still require further examination.

Alcyonium is considered as a potential source for nitrogenous and non-nitrogenous terpenoidal derivatives. By the way, $A$. paessleri produces rare nitrogen containing illudalane sesquiterpene (alcyopterosins B, C, E, F, G, H, J and M) [29]. Thus, this review focused on elaborating the future plan for the natural products researchers to investigate the disremembered genus Alcyonium.

\section{Conclusions}

Alcyonium could be considered as a potential source of bioactive terpenoidal metabolites. The engagement of different approaches played a significant role in the facilitation of the forthcoming drug discovery process. Remarkable, many marine metabolites displaying fascinating molecular structures with diverse pharmacological effects have been reported from genus Alcyonium during the last four decades (1981-2019). Of the 92 distinctive structures accounted for in this review, 67 (72.8\%) are terpenoidal metabolites.

Figure 12 illustrates terpenoidal metabolites produced by 16 species. The majority $(41.8 \%)$ of the presented compounds were produced by three species; A. paessleri (17 compounds, $18.5 \%$ ), A. coralloides (12 compounds, $12.0 \%$ ) and $A$. gracillimum (11 compounds, $12.0 \%$ ), respectively.

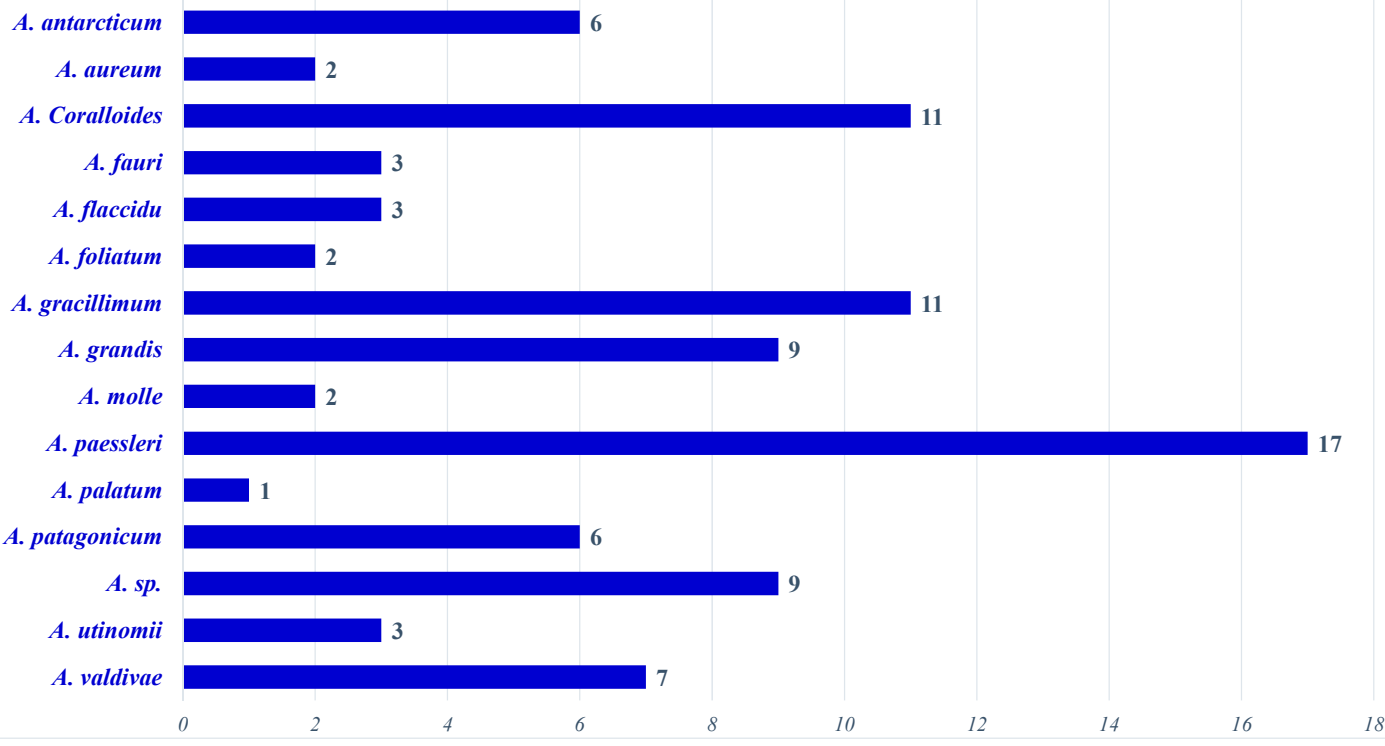

Figure 12. Number of compounds reported from Alcyonium species. 
Funding: This research received no external funding.

Conflicts of Interest: The authors declare no conflict of interest.

\section{References}

1. Newman, D.J.; Cragg, G.M. Drugs and Drug Candidates from Marine Sources: An Assessment of the Current "state of Play". Planta Med. 2016, 82, 775-789. [CrossRef] [PubMed]

2. Arrieta, J.M.; Arnaud-Haond, S.; Duarte, C.M.; Gaines, S.D. What lies underneath: Conserving the oceans' genetic resources. Proc. Natl. Acad. Sci. USA 2010, 107, 18318-18324. [CrossRef] [PubMed]

3. McFadden, C.S.; Ofwegen, L.P. VAN Revisionary systematics of the endemic soft coral fauna (Octocorallia: Alcyonacea: Alcyoniina) of the Agulhas Bioregion, South Africa. Zootaxa 2017, 4363, 451-488. [CrossRef]

4. WoRMS-World Register of Marine Species. Available online: http:/ / www.marinespecies.org (accessed on 5 April 2019).

5. Gage, J.D.; Tyler, P.A. Deep-Sea Biology, A Natural History of Organisms at the Deep-Sea Floor; Cambridge University Press: Cambridge, UK, 1992.

6. Shang, J.; Hu, B.; Wang, J.; Zhu, F.; Kang, Y.; Li, D.; Sun, H.; Kong, D.X.; Hou, T. Cheminformatic Insight into the Differences between Terrestrial and Marine Originated Natural Products. J. Chem. Inf. Model. 2018, 58, 1182-1193. [CrossRef] [PubMed]

7. Blunt, J.W.; Copp, B.R.; Keyzers, R.A.; Munro, M.H.G.; Prinsep, M.R. Marine natural products. Nat. Prod. Rep. 2017, 34, 235-294. [CrossRef]

8. Núñez-Pons, L.; Carbone, M.; Vázquez, J.; Gavagnin, M.; Avila, C. Lipophilic defenses from Alcyonium soft corals of Antarctica. J. Chem. Ecol. 2013, 39, 675-685. [CrossRef] [PubMed]

9. Hegazy, M.E.F.; Mohamed, T.A.; Alhammady, M.A.; Shaheen, A.M.; Reda, E.H.; Elshamy, A.I.; Aziz, M.; Paré, P.W. Molecular architecture and biomedical leads of terpenes from Red Sea marine invertebrates. Mar. Drugs 2015, 13, 3154-3181. [CrossRef]

10. Choudhary, A.; Naughton, L.M.; Mont, I.; Dobson, A.D.W.; Rai, D.K. Current Status and Future Prospects of Marine Natural Products (MNPs) as Antimicrobials. Mar. Drugs 2017, 15, 272. [CrossRef]

11. Kong, D.X.; Jiang, Y.Y.; Zhang, H.Y. Marine natural products as sources of novel scaffolds: Achievement and concern. Drug Discov. Today 2010, 15, 884-886. [CrossRef]

12. Tripathi, V.C.; Satish, S.; Horam, S.; Raj, S.; lal, A.; Arockiaraj, J.; Pasupuleti, M.; Dikshit, D.K. Natural products from polar organisms: Structural diversity, bioactivities and potential pharmaceutical applications. Polar Sci. 2018, 18, 147-166. [CrossRef]

13. Fine, M.; Cinar, M.; Voolstra, C.R.; Safa, A.; Rinkevich, B.; Laffoley, D.; Hilmi, N.; Allemand, D. Coral reefs of the Red Sea-challenges and potential solutions. Reg. Stud. Mar. Sci. 2019, 25, 100498. [CrossRef]

14. Alarif, W.M.; Abdel-Lateff, A.; Alorfi, H.S.; Alburae, N.A. Alcyonacea: A Potential Source for Production of Nitrogen-Containing Metabolites. Molecules 2019, 24, 286. [CrossRef]

15. Chanmethakul, T.; Chansang, H.; Watanasit, S. Soft coral (Cnidaria: Alcyonacea) distribution patterns in Thai waters. Zool. Stud. 2010, 49, 72-84.

16. Mayer, A.M.S.; Glaser, K.B.; Cuevas, C.; Jacobs, R.S.; Kem, W.; Little, R.D.; McIntosh, J.M.; Newman, D.J.; Potts, B.C.; Shuster, D.E. The odyssey of marine pharmaceuticals: A current pipeline perspective. Trends Pharmacol. Sci. 2010, 31, 255-265. [CrossRef]

17. König, G.M.; Kehraus, S.; Seibert, S.F.; Abdel-Lateff, A.; Müller, D. Natural products from marine organisms and their associated microbes. ChemBioChem 2006, 7, 229-238. [CrossRef]

18. Faulkner, D.J. Marine pharmacology. Antonie van Leeuwenhoek. Int. J. Gen. Mol. Microbiol. 2000, 77, 135-145.

19. Newman, D.J.; Cragg, G.M. Current Status of Marine-Derived Compounds as Warheads in Anti-Tumor Drug Candidates. Mar. Drugs 2017, 15, 99. [CrossRef]

20. McFadden, C.; van Ofwegen, L. Molecular phylogenetic evidence supports a new family of octocorals and a new genus of Alcyoniidae (Octocorallia, Alcyonacea). Zookeys 2013, 346, 59-83. [CrossRef]

21. Mcfadden, C.S.; Donahue, R.; Hadland, B.K.; Weston, R. A molecular phylogenetic analysis of reproductive trait evolution in the soft coral genus alcyonium published by: The society for the study of evolution a molecular phylogenetic analysis of reproductive trait evolution in the soft coral genus alcyonium. Evolution 2001, 55, 54-67. [CrossRef] 
22. Bowden, B.B.F.; Coll, J.J.C.; Tapiolas, D.M.D. Studies of Australian Soft Corals. XXX A Novel Trisnorsesquiterpene from a Cespitularia Species and the Isolation of Guaiazulene from a Small Blue Alcyonium Species. Aust. J. Chem. 1983, 36, 211-214. [CrossRef]

23. Guerriero, A.; Dematté, B.; D'Ambrosio, M.; Pietra, F. (+)-Coralloidin-A and (-)-Coralloidin-B, Two New Sesquiterpenoids from the Mediterranean Alcyonacean Alcyonium coralloides. J. Nat. Prod. 1986, 49, 608-613. [CrossRef]

24. D'Ambrosio, M.; Guerriero, A.; Pietra, F. Coralloidin C, D, and E: Novel Eudesmane Sesquiterpenoids from the Mediterranean Alcyonacean Alcyonium coralloides. Helv. Chim. Acta 1987, 70, 612-620.

25. Pika, J.; Faulkner, D.J. Four sesquiterpenes from the South African nudibranch Leminda millecra. Tetrahedron. J. Nat. Prod. 1994, 50, 3065-3070. [CrossRef]

26. McPhail, K.L.; Davies-Coleman, M.T.; Starmer, J. Sequestered chemistry of the Arminacean nudibranch Leminda millecra in Algoa Bay, South Africa. J. Nat. Prod. 2001, 64, 1183-1190. [CrossRef] [PubMed]

27. Cimino, G.; De Rosa, S.; De Stefano, S.; Sodano, G. A new furanosesquiterpene from the Mediterranean Alcyonacean Alcyonum Palmatum. J. Nat. Prod. 1984, 47, 877-878. [CrossRef]

28. Hooper, G.J.; Davies-Coleman, M.T. Sesquiterpene hydroquinones from the South African soft coral Alcyonium fauri. Tetrahedron Lett. 1995, 36, 3265-3268. [CrossRef]

29. Palermo, J.A.; Brasco, M.F.; Spagnuolo, C.; Seldes, A.M. Illudalane sesquiterpenoids from the soft coral Alcyonium paessleri: The first natural nitrate esters. J. Org. Chem. 2000, 65, 4482-4486. [CrossRef] [PubMed]

30. Rodríguez Brasco, M.F.; Seldes, A.M.; Palermo, J.A. Paesslerins A and B: Novel Tricyclic Sesquiterpenoids from the Soft Coral Alcyonium Paessleri. Org. Lett. 2001, 3, 1415-1417. [CrossRef]

31. Carbone, M.; Núñez-Pons, L.; Castelluccio, F.; Avila, C.; Gavagnin, M. Illudalane Sesquiterpenoids of the Alcyopterosin Series from the Antarctic Marine Soft Coral Alcyonium grandis. J. Nat. Prod. 2009, 72, 1357-1360. [CrossRef]

32. Manzo, E.; Ciavatta, M.L.; Nuzzo, G.; Gavagnin, M. Terpenoid content of the Antarctic soft coral Alcyonium antarcticum. Nat. Prod. Commun. 2009, 4, 1615-1619. [CrossRef]

33. Kashman, Y.; Carmely, S.; Groweiss, A. Further Cembranoid Derivatives from the Red Sea Soft Corals Alcyonium flaccidum and Lobophytum crassum. J. Org. Chem. 1981, 46, 3592-3596. [CrossRef]

34. Kinamoni, Z.; Groweiss, A.; Carmely, S.; Kashman, Y.; Loya, Y. Several new cembranoid diterpenes from three soft corals of the red sea. Tetrahedron 1983, 39, 1643-1648. [CrossRef]

35. Ambrosio, M.D.; Fabbri, D.; Guerriero, A.; Pietra, F.; Chimica, I.; Trento, U. Coralloidolide A and Coralloidolide B, the First Cembranoids from a Mediterranean Organism, the Alcyonacean Alcyonium coralloides. Helv. Chim. Acta 1986, 70, 63-70. [CrossRef]

36. D'Ambrosio, M.; Guerriero, A.; Pietra, F. Novel cembranolides (Coralloidolide D and E) and a 3,7-Cyclized cembranolide (Coralloidolide C) from the mediterranean coral Alcyonium coralloides. Helv. Chim. Acta 1989, 72, 1590-1596. [CrossRef]

37. D'Ambrosio, M.; Guerriero, A.; Pietra, F. Coralloidolide F, the First Example of a 2,6-Cyclized Cembranolide: Isolation from the Mediterranean Alcyonacean Coral Alcyonium coralloides. Helv. Chim. Acta 1990, 73, 804-807. [CrossRef]

38. Kobayashi, M.; Yasuzawa, T.; Kobayashi, Y.; Kyogoku, Y.; Kitagawa, I. Alcyonolide, a novel diterpenoid from a soft coral. Tetrahedron Lett. 1981, 22, 4445-4448. [CrossRef]

39. Coll, J.C.; Kearns, P.S.; Rideout, J.A. Isolation of a novel diterpene triacetate from two soft corals of the order Alcyonacea. J. Nat. Prod. 1998, 61, 835-837. [CrossRef]

40. Bowden, B.F.; Coll, J.C.; Dai, M.C. Studies of australian soft corals. XLIII the structure elucidation of a new diterpene from Alcyonium molle. Aust. J. Chem. 1989, 42, 665-673. [CrossRef]

41. Su, J.; Zheng, Y.; Zeng, L.; Pordesimo, E.O.; Schmitz, F.J.; Hossain, M.B.; van der Helm, D. Patagonicol: A diterpenoid from the Chinese soft coral Alcyonium patagonicum. J. Nat. Prod. 1993, 56, 1601-1604. [CrossRef]

42. Lin, Y.; Bewley, C.A.; Faulkner, D.J.J. The valdivones, anti-inflammatory diterpene esters from the South African soft coral Alcyonium valdivae. Tetrahedron 1993, 49, 7977-7984. [CrossRef]

43. Zubia, E.; Spinella, A.; Giusto, G.B.; Crispinoand, A.; Cimino, G. A new diterpenoid skeleton from the Mediterranean octocoral Alcyonium palmatum: Structure of palmatol. Tetrahedron Lett. 1994, 35, 7069-7072. [CrossRef] 
44. Rudi, A.; Ketzinel, S.; Goldberg, I.; Stein, Z.; Kashman, Y.; Benayahu, Y.; Schleyer, M. Antheliatin and Zahavins A and B, three new cytotoxic xenicane diterpenes from two soft corals. J. Nat. Prod. 1995, 58, 1581-1586. [CrossRef]

45. Missakian, M.G.; Burreson, B.J.; Scheuer, P.J. Pukalide, a furanocembranolide from the soft coral Sinularia abrupta. Tetrahedron 1975, 31, 2513-2515. [CrossRef]

46. Kobayashi, M.; Kanda, F.; Damarla, S.R.; Rao, D.V.; Rao, C.B. Marine sterols. XVII. Polyhydroxysterols of the soft corals of the andaman and nicobar coasts. (2). Isolation and atructures of three $16 \beta$-hydroxy steroidal glycosides from an Alcyonium sp. soft coral. Chem. Pharm. Bull. 1990, 38, 2400-2403. [CrossRef]

47. Chen, W.-C.; Sheuz, J.-H.; Fangy, L.-S.; Hux, W.-P.; Sung, P.-J. $3 \alpha, 7 \alpha, 12 \alpha$-Triacetoxy-5 $\beta$-cholanic acid, a steroid from the Formosan soft coral Alcyonium sp. (Alcyoniidae). Nat. Prod. Res. 2006, 20, 748-753. [CrossRef]

48. Kobayashi, M.; Kiyota, Y.; Orito, S.; Kyogoku, Y.; Kitagawa, I. Five new steroidal glycosides, pregnedioside-A, -B, and their three monoacetates, from an Okinawan soft coral of Alcyonium sp. Tetrahedron Lett. 1984, 25, 3731-3734. [CrossRef]

49. Tomono, Y.; Hirota, H.; Imahara, Y.; Fusetani, N. Four new steroids from two octocorals. J. Nat. Prod. 1999, 62, 1538-1541. [CrossRef]

50. Seo, Y.; Jung, J.H.; Rho, J.-R.; Shin, J.; Song, J.-I. Isolation of novel bioactive steroids from the soft coral Alcyonium gracillimum. Tetrahedron 1995, 51, 2497-2506. [CrossRef]

51. Ruzicka, L. The isoprene rule and the biogenesis of terpenic compounds. Experientia 1953, 9, 357-367. [CrossRef]

52. Blunt, J.W.; Copp, B.R.; Munro, M.H.G.; Northcote, P.T.; Prinsep, M.R. Marine natural products. Nat. Prod. Rep. 2005, 22, 15-61. [CrossRef]

53. Fraga, B.M. Natural sesquiterpenoids. Nat. Prod. Rep. 2005, 22, 465-486. [CrossRef]

54. Hanson, J.R. The sesterterpenoids. Nat. Prod. Rep. 1996, 3, 529-535. [CrossRef]

55. Coll, J.C.; Bowden, B.F.; Tapiolas, D.M.; Willis, R.H.; Djura, P.; Streamer, M.; Trott, L. The terpenoid chemistry of soft corals and its implications. Tetrahedron 1985, 41, 1085-1092. [CrossRef]

56. Hay, M.E.; Fenical, W. Marine plant-herbivore interactions: The ecology of chemical defense. Ann. Rev. Ecol. Syst. 1988, 19, 111-145. [CrossRef]

57. Minale, L.; Iorizzi, M.; Palagiano, E.; Riccio, R. Steroid and triterpenoid oligogylcosides of marine origin. Adv. Exp. Med. Biol. 1996, 404, 335-356. [PubMed]

58. Djerassi, C. Recent studies in the marine sterol field. Pure Appl. Chem. 1981, 53, 873-890. [CrossRef]

59. Hanson, J.R. Diterpenoids. Nat. Prod. Rep. 2005, 22, 594-602. [CrossRef] [PubMed]

60. Pennock, J.F. Terpenoids in marine invertebrates. Int. Rev. Biochem. 1977, 14, 153-213.

61. Andersen, R.J.; De Silva, E.D.; Dumdei, E.J.; Northcote, P.T.; Pathirana, C.; Tischler, M. Terpenoids from selected marine invertebrates. In Recent Advances in Phytochemistry; Towers, G.H.N., Stafford, H.A., Eds.; Plenum Press: New York, NY, USA, 1990; Volume 24, pp. 265-282.

62. Bakus, G.J.; Targett, N.M.; Schulte, B. Chemical ecology of marine organisms: An overview. J. Chem. Ecol. 1986, 12, 951-987. [CrossRef] [PubMed]

63. Hay, M.E. Marine chemical ecology: What's known and what's next? J. Exp. Mar. Biol. Ecol. 1996, 200, 103-134. [CrossRef]

64. Connolly, J.D.; Hill, R.A. Triterpenoids. Nat. Prod. Rep. 2005, 22, 487-503. [CrossRef]

65. Paul, V.J.; Puglisi, M.P. Chemical mediation of interactions among marine organisms. Nat. Prod. Rep. 2004, 21, 189-209. [CrossRef]

66. Coll, J.C. The chemistry and chemical ecology of octocorals (Coelenterata, Anthozoa, Octocorallia). Chem. Rev. 1992, 92, 613-631.

67. Fusetani, N. Biofouling and antifouling. Nat. Prod. Rep. 2004, 21, 94-104. [CrossRef]

68. McClintock, J.B.; Baker, B.J. A review of the chemical ecology of Antarctic marine invertebrates. Am. Zool. 1997, 37, 329-342. [CrossRef]

69. Proksch, P. Defensive roles for secondary metabolites from marine sponges and sponge-feeding nudibranchs. Toxicon 1994, 32, 639-655. [CrossRef]

70. Zubair, M.; Alarif, W.M.; Al-Footy, K.O.; PH, M.; Aly, M.; Basaif, S.; Al-Lihaibi, S.; Ayyad, S.-E. New antimicrobial biscembrane hydrocarbon and cembranoid diterpenes from the soft coral Sarcophyton trocheliophorum. Turk. J. Chem. 2016, 40, 385-392. [CrossRef] 
71. Welford, A.J.; Collins, I. The 2,11-cyclized cembranoids: Cladiellins, asbestinins, and briarellins (period 1998-2010). J. Nat. Prod. 2011, 74, 2318-2328. [CrossRef]

72. Hsiao, T.-H.; Sung, C.-S.; Lan, Y.-H.; Wang, Y.-C.; Lu, M.-C.; Wen, Z.-H.; Wu, Y.-C.; Sung, P.-J. New Anti-Inflammatory Cembranes from the Cultured Soft Coral Nephthea columnaris. Mar. Drugs 2015, 13, 3443-3453. [CrossRef]

73. Hsiao, T.-H.; Cheng, C.-H.; Wu, T.-Y.; Lu, M.-C.; Chen, W.-F.; Wen, Z.-H.; Dai, C.-F.; Wu, Y.-C.; Sung, P.-J. New Cembranoid Diterpenes from the Cultured Octocoral Nephthea columnaris. Molecules 2015, 20, 13205-13215. [CrossRef]

74. Huang, H.-W.; Tang, J.-Y.; Ou-Yang, F.; Wang, H.-R.; Guan, P.-Y.; Huang, C.-Y.; Chen, C.-Y.; Hou, M.-F.; Sheu, J.-H.; Chang, H.-W. Sinularin Selectively Kills Breast Cancer Cells Showing G2/M Arrest, Apoptosis, and Oxidative DNA Damage. Molecules 2018, 23, 849. [CrossRef]

75. Noah, C.-A.; Wu, W.-T.; Dai, G.-F.; Su, J.-H.; Liu, C.-I.; Su, T.-R.; Wu, Y.-J. Flaccidoxide-13-Acetate Extracted from the Soft Coral Cladiella kashmani Reduces Human Bladder Cancer Cell Migration and Invasion through Reducing Activation of the FAK/PI3K/AKT/mTOR Signaling Pathway. Molecules 2018, 23, 58. [CrossRef]

76. Lee, Y.-S.; Duh, T.-H.; Siao, S.-S.; Chang, R.-C.; Wang, S.-K.; Duh, C.-Y. New Cytotoxic Terpenoids from Soft Corals Nephthea chabroli and Paralemnalia thyrsoides. Mar. Drugs 2017, 15, 392. [CrossRef]

77. Wu, J.; Xi, Y.; Huang, L.; Li, G.; Mao, Q.; Fang, C.; Shan, T.; Jiang, W.; Zhao, M.; He, W.; et al. A Steroid-Type Antioxidant Targeting the Keap1/Nrf2/ARE Signaling Pathway from the Soft Coral Dendronephthya gigantea. J. Nat. Prod. 2018, 81, 2567-2575. [CrossRef]

78. Wu, Q.; Li, H.; Yang, M.; Jia, A.-Q.; Guo, Y.-W. Two new cembrane-type diterpenoids from the xisha soft coral Lemnalia flava. Fitoterapia 2019, in press. [CrossRef]

79. Zhang, Q.; Liang, L.-F.; Miao, Z.-H.; Wu, B.; Guo, Y.-W. Cytotoxic polyhydroxylated steroids from the South China Sea soft coral Lobophytum sp. Steroids 2019, 141, 76-80. [CrossRef]

80. Zhang, Q.; Li, X.-W.; Yao, L.-G.; Wu, B.; Guo, Y.-W. Three new capnosane-type diterpenoids from the South China Sea soft coral Lobophytum sp. Fitoterapia 2019, 133, 70-74. [CrossRef]

81. Wu, Q.; Li, X.-W.; Li, H.; Yao, L.-G.; Tang, W.; Miao, Z.-H.; Wang, H.; Guo, Y.-W. Bioactive polyoxygenated cembranoids from a novel Hainan chemotype of the soft coral Sinularia flexibilis. Bioorg. Med. Chem. Lett. 2019, 29, 185-188. [CrossRef] 